\title{
Promoting Teachers' SKILls of INSTRUCTIONAL MATERIALS IMPROVISATION THROUGH WORKSHOPS AND EXHIBITIONS IN Calabar METROPOlis, Nigeria
}

\author{
Ekpo O. Ekpo-Eloma and Abigail Aniefiok Effiong \\ Department of Curriculum and Teaching, University of Calabar, Calabar
}

\begin{abstract}
The study examined the effect of workshops/exhibitions on teachers' instructional materials improvisatonal skills for enhanced service delivery in secondary schools in Calabar Metropolis, Nigeria. Two hypotheses were formulated to guide the study. A sample of 160 teachers was drawn from eight secondary schools in the study area, using stratified random sampling technique. Two instruments sampling the same contents, titled Pre-knowledge and Post-Knowledge Instructional Material Improvisation Questionnaire were used to elicit responses from teachers, administered at different intervals. At the end the one week practical session and administration of the second questionnaire, independent statistical technique was used to collate the scores of the administered questionnaires. The result of data showed that workshops/exhibitions had significant effect on teachers' improvisational skills. Therefore, it was recommended that regular workshops/Exhibitions be organized for teachers to improve their wits on production and utilization of instructional materials.
\end{abstract}

\section{KEYWORDS}

Promoting, Teachers' Skills, Improvisation, Instructional Materials, Workshops, Exhibitions.

\section{INTRODUCTION}

The very essence of any teaching-learning encounter is to enhance optimal learning. This involves the systematic transfer of knowledge, skills and values to the learners in ways that are learner-friendly. Teachers have divergent views on how teaching and learning can be effectively consummated with the view to sustaining learners' interests. Most teachers, especially those in pre-primary and post-primary levels of education, believe that effective instruction can be actualized by oppressively depositing curriculum contents on learners, and the latter assimilating such contents sheepishly (Banking concept of education). They equally reasoned that effective instruction can be achieved through intimidation, nagging or flogging of learners. Learners detaste or loathe this highly mechanistic and dehumanizing approach to knowledge impartation. Meaningful learning can be easily achieved and sustained by adopting, appropriate learning methodologies garnished with appropriate and attention-compelling instructional materials in a democratic learning environment.

These materials (audio, visuals, audio-visuals, tactile, olfactory, gustatory and kinesthetic materials) are, for most times, limited in supply or non-evident. The appropriate integration of these materials in classroom pedagogy, in quality and quantity, is capable of arousing learners' curiosity, interest, direct purposeful learning experience (Inyang-Abia, 2015 ${ }^{[1]}$, Ibe-Bassey, 2005 ${ }^{[2]}$; Ekpo-Eloma, 2007 $7^{[3]}$ ). Learners are usually excited and curious when exposed to 
experiences that transcend beyond mere information dissemination or teaching by "telling". Albert Bandura's social modeling theory emphasizes "telling" and "showing" during instruction to concretize learning.

The use of instructional materials have been acknowledged to boost quality instruction (InyangAbia, 2015 ${ }^{[1]}$; Mangal and Mangal, 2009 ${ }^{[4]}$; Elekwa and Eze, 2002[5]). Meanwhile, teachers do not have the skills to produce and use these materials during instruction. As part of their professional training, teachers ought to show demonstrable skills in the sourcing, fabrication and utilization of instructional materials, especially given the present economic situation. However, the few that have the skills to produce, see this aspect of teacher training as mere waste of time, energy and resources. This situation can be ameliorated and production of materials scaled up through workshops and exhibitions, facilitated by experts and professionals. Teachers' exposure to the skills of instructional material production would take them out of their present improvisational quagmire and doldrumcy and rekindle their interest in production. Workshops and exhibitions will help sharpen teachers' wits in the area of improvisation. Teachers' participation and engagement in workshops and exhibitions will link them to limitless opportunities that will enable them express or maximize their production potentials.

A workshop is a brief intensive course of study involving a small group of experts and nonexperts interacting and providing practical solutions to educational problems. It is a period when facilitators impacts knowledge and practical skills on teachers to enable them design and produce instructional materials using available technology.

Shepard $(1999)^{[6]}$ outlines the objectives of workshops to include:

i. To find out the current use of instructional materials for visual arts in schools/colleges.

ii. To design and construct selected teaching-learning materials for use in schools/colleges.

iii. To identify and describe the steps involved in production of instructional materials.

iv. To test the efficacy of instructional materials.

v. To assist teachers find and create useful materials on their own.

Exhibitions, on the other hand, are large scale public showing of objects and products of such workshops. Exhibitions are a means of practically showcasing and evaluating a learning experience attained at any given time. Exhibitions promote a deeper perspective on how instructional materials can be produced. Presenting live demonstrations of how these materials are fabricated sheds more light and promotes the spirit of creativity and resourcefulness.

Workshops and exhibitions, undoubtedly, offer opportunities for direct purposeful learning experience and practical application of improvisational skills. It further provides hands-onpractical skills with technological tools as participants, under the guidance of mentors, learn to integrate technology into the curriculum process. Shepard $(1999)^{[6]}$ outlines the objectives and workshops to include:

i. To find out the current use of instructional materials for visual arts in schools/colleges.

ii. To design and construct selected teaching-learning materials for use in schools/colleges.

iii. To identify and describe and describe the steps involved in production of instructional materials.

iv. To test the efficacy of instructional materials in schools/colleges.

v. To assist teachers find and create useful materials on their own. 
International Journal on Integrating Technology in Education (IJITE), Vol.10, No.4, December 2021

He further maintains that workshops/exhibitions will encourage both teachers and teachertrainees to prepare their own teaching-learning materials using local resources and tools. when workshop participants acquire the necessary improvisational skills they will be highly motivated to produce and use their own materials during any teaching-learning encounter.

When teachers participate in regular workshops on improvisation, it would expose them to where these materials can be sourced (local communities, farms, markets, carpenters workshops and other workshops, museums, monuments, arts and galleries, schools/colleges, donations, libraries, etc); levels of production (originality/creativity level, adaptive level, cookbook construction level); tools for production (cutting, colouring and lettering tools); and skills of improvisation (calibration, creativity, observation, colouring, monitoring, etc).

\subsection{Statement of Problem}

Instructional materials are valuable assets to teachers and learners, especially in this era of paradigm shift with emphasis on the learner. It is one thing to produce and another to judiciously utilize instructional materials to titillate classroom pedagogy. In spite of the fact that most of these materials are strewn around the environment, they are, for most times, abandoned or underutilized. Perhaps, these materials are allowed to lie fallow because most teachers do not have the requisite skills to source for or fabricate them into functional tools for instructional delivery. Instances abound where materials supplied to schools are stockpiled in rooms, under lock and key, for years or at the mercy of cobwebs and rodents. Perhaps, some these materials are allowed to fallow or lie latent because most teachers lack the technical knowhow to produce and/or manipulate them. This does not suggest that other variables like lack of electricity supply especially for projectuals) may inhibit their effective utilization. Other reasons may include the classroom environment, duration of the lesson, teaching methods, etc. It is, however, contemplated that if regular workshops and exhibitions are mounted for all shades of teachers, under the tutelage of experts, supervisors or professionals (on instructional material production), it will motivate teachers' interest to produce and use these materials through cross fertilization of ideas. This is the central issue this paper attempts to investigate.

\subsection{Purpose of the study}

The purpose of this study is to examine the effect of workshops/exhibitions on teachers' skills of improvisation of instructional materials. Specifically, the study examines the:

i. Effect of workshops/exhibitions on teachers' skill of production of instructional materials.

ii. Effect of workshops/exhibitions on teachers' skill of utilization of instructional materials.

\section{Research questions}

Two research questions were generated to guide the study.

i. What is the effect of workshops/exhibitions on teachers' skills of production of instructional materials?

ii. What is the effect of workshops/exhibitions on teachers' skills of utilization of instructional materials/ 
International Journal on Integrating Technology in Education (IJITE), Vol.10, No.4, December 2021

\section{Research hypothesis}

The following hypotheses were formulated to guide the study.

i. Workshops/exhibitions have no significant effect on teachers' skills of production of instructional materials.

ii. Workshop/exhibitions have no significant effect on teachers' skills of utilization of instructional materials.

\subsection{Methodology}

\section{Research Design}

Ex-post facto research design was adopted for this study because teachers used for the study had already undergone a one-week workshop/exhibitions programme on improvisation of instructional materials organized by the government.

\subsection{Area of study}

The study was conducted in Calabar Metropolis, Nigeria. It is made up of Calabar Municipality and Calabar South Local Government Areas. The entire landscape is inundated with an avalanche of instructional materials which can be effectively galvanized and apprehended for the purposes of instruction. Unfortunately, most of these resources are lying latent due to teachers' complacency or cognitive poverty on their development and or utilization. The area has a wide range of educational institutions - nursery, primary, secondary schools and three tertiary institutions, which should depend on these educational resources to enhance direct purposeful learning experience.

\subsection{Sample}

The sample consisted of 160 secondary school teachers ( Male: 76, Female: 84) drawn from eight (8) secondary schools in Calabar Metropolis, Nigeria as shown in Table 1.

Table 1: Showing sample used for the study

\begin{tabular}{|c|c|c|c|c|c|}
\hline S/no & School & LGA & Male & Female & Total \\
\hline 1. & A & Calabar Municipality & 12 & 8 & 20 \\
\hline 2. & B & Calabar Municipality & 07 & 13 & 20 \\
\hline 3. & $\mathrm{C}$ & Calabar Municipality & 09 & 11 & 20 \\
\hline 4. & $\mathrm{D}$ & Calabar Municipality & 10 & 10 & 20 \\
\hline 5. & $\mathrm{E}$ & Calabar South & 12 & 08 & 20 \\
\hline 6. & $\mathrm{~F}$ & Calabar South & 07 & 13 & 20 \\
\hline 7. & G & Calabar South & 11 & 09 & 20 \\
\hline 8. & $\mathrm{H}$ & Calabar South & 8 & 12 & 20 \\
\hline \multicolumn{3}{|c|}{ Total } & 76 & 84 & 160 \\
\hline
\end{tabular}

Source: Field survey 


\subsection{Sampling technique}

The stratified random sampling technique was adopted for the study. First, the area was stratified into two local government areas: Calabar Municipality and Calabar South, all in Calabar Metropolis. In each area, four secondary schools were selected using the "hat" and "draw" balloting technique. The same method was used in selecting 20 teachers from each school. In the hat and draw method, 30 pieces of papers, containing 20 (Yes) and 10 (No) were designed for each of the eight schools used for the study. All the 160 teachers who picked Yes were immediately issued a pre-knowledge instructional material improvisational questionnaire, while those who picked No were excluded from the study.

\subsection{Instrumentation}

Two sets of questionnaires containing the same items, except for the difference in title (Preknowledge instructional material improvisation questionnaire and Post-knowledge instructional material questionnaire), were developed by the researchers and administered on the respondents (workshop/exhibition participants or teachers). The 20 item questionnaire consisted of Parts A and B. Part A elicited information on participants' demographic characteristics (Name of school and gender). Part B addressed the contextual issues of the study. The first nine (9) items centred around instructional material production skills, while the last nine (9) items ferreted information on instructional materials utilization/skills). The items were developed based on a 4-point Likert scale of strongly agree, agree, disagree and strongly disagree (See Appendix).

\subsection{Validation of instruments}

The instruments were given to three experts, one in Research, and the other two in Educational Technology for indepth study and validation. Their comments and suggestions were used to fair up the questionnaires used for the study.

\subsection{Reliability of instrument}

To determine the reliability of the instrument, it was trial tested on twenty (20) respondents drawn from the study area not used for the actual study. The questionnaire was administered twice to the same set of teachers after an interval of two (2) weeks. When the scores of the two tests were collated, a reliability index of $0.86-0.88$ was obtained.

\subsection{Administration and Collection of Data}

Data administration lasted for a period one week. The pre-knowledge instructional material production and utilization questionnaires were administered on the 160 respondents. On completion and submission of the questionnaire, a one week intensive workshop and exhibition was mounted by professionals/experts on instructional material production/utilization. Areas covered included meaning and usefulness of instructional materials, sources and levels of production, cutting, colouring and lettering tools, utilization strategies including ASSURE model as well as the management of these materials. Participants were then given the opportunity to produce and showcase their production. The workshop ended up with an exhibition of materials produced by participants and experts. At the end of the workshop, the same questionnaire but retitled "Post-knowledge Instructional Material Production and Utilization Questionnaire" was readministered, and data collected was collated and compared with their earlier responses and subjected to data analysis as presented in Tables 2 and 3. 
International Journal on Integrating Technology in Education (IJITE), Vol.10, No.4, December 2021

\section{DisCuSSION OF RESUlts}

The independent t-test analysis was used to test the two hypotheses at .05 level of significance and 158 degree of freedom as presented in Tables 2 and 3.

Hypothesis one This hypotheses states that workshops/exhibitions have no significant effect on teachers' skills of production of instructional materials. The summary of the result is presented in Table 2.

Table 2: Independent t-test analysis of the effect of workshops/exhibitions on teachers' skills of production of instructional materials $(n=160)$

\begin{tabular}{lcccc}
\hline \hline Workshops/exhibitions & $\mathrm{n}$ & $\overline{\mathrm{X}}$ & $\mathrm{SD}$ & $\mathrm{t}$-value \\
\hline High productivity & 83 & 19.60 & 2.37 & $5.22^{*}$ \\
& & & & \\
Low productivity & 77 & 17.61 & 2.44 \\
\hline \hline
\end{tabular}

Significant at .05 level, $\mathrm{df}=158$; critical $\mathrm{t}=196$

The result in Table 2 shows that the calculated t-value of 5.22 is higher the critical t-value of 1.95 at .05 level of significance with 158 degree of freedom. This, the null hypothesis has been rejected in favour of the alternate hypothesis. This means that workshops/exhibitions have significant effect on teachers' skills of production and utilization of instructional materials. The implication is that when teachers are exposed to regular workshops and exhibitions, it will propel them to sustainably produce instructional materials for effective classroom instructional delivery.

The benefits of workshops include to:

Discover practical ways that help one stay focus, promote team work and more collaboration as well as enhance effective communication (www.art.com.sg>theartofimprovisationthesyngaporereprentorytheatre). According to Shepard (1999) ${ }^{[6]}$, workshops and exhibitions will help teachers and students grasp the techniques and skills of producing their own materials using local materials and tools.

\section{Hypothesis two}

This hypothesis states that workshops and exhibitions have no significant effect on teachers' utilization of instructional materials. To test this hypothesis, independent t-test analysis was used and the summary of the result presented in Table 3.

Table 3: Independent t-test analysis of the effect of workshops/exhibitions on teachers' skills of utilization of instructional materials $(n=160)$

\begin{tabular}{lcccc}
\hline \hline Workshops/exhibitions & $\mathrm{n}$ & $\overline{\mathrm{X}}$ & $\mathrm{SD}$ & $\mathrm{t}$-value \\
\hline Frequent utilization & 99 & 19.41 & 2.11 & \\
& & & & $4.61^{*}$ \\
& & & & \\
Poor utilization & 61 & 17.62 & 2.09 & \\
\hline \hline
\end{tabular}

Significant at .05 level, $\mathrm{df}=158$; critical $\mathrm{t}=196$ 
International Journal on Integrating Technology in Education (IJITE), Vol.10, No.4, December 2021

The result presented in Table 3 shows that the calculated t-value of 4.61 is higher than the critical t-value of 1.96 at .05 level of significance, with 158 degree of freedom. With this result, the null hypothesis has been rejected. This signifies that workshops and exhibitions promote effective utilization of instructional materials in the teaching-learning process. This is in tandem with Romiszowski (1988) ${ }^{[7]}$ that of teachers lack basic instructional materials the effectiveness of their lesson delivery will be limited.

Exhibitions and workshops promptly deepened viewing experience leading to new insights. One benefit of improvisation (production and use) is that teachers feel more comfortable utilizing materials produced by them having spent time, energy and resources fabricating these materials (Ekpo-Eloma, 2021)[8]. Workshops and exhibitions offer opportunity for direct purposeful learning experience and practical application of improvised materials in instructional delivery.

In a study carried out by Goldstein and Ropo (2021)[9]on students teachers training for ICT based teaching using a sample of 85 student-teachers, the result showed that most studentteachers with training on ICT performed significantly.

\section{CONCLUSION AND RECOMMENDATIONS}

Instructional materials remain core, not supplementary, in the teaching-learning process. These materials help concretize learning, and thus remain a good recipe for effective instructional delivery. Given the importance of Instructional materials in the teaching-learning process teachers should be encouraged to use them to deliver instructional contents. This can be achieved by exposing teachers to regular workshops and exhibitions as a means of sharpening their wits and hands-on experience in the production and use of these curriculum resources. If teachers are not exposed to these interactive sessions, they would be the most vulnerable. Government should mount workshops and exhibitions, on a regular basis, to promote improvisational skills of production and utilization of instructional materials. Special funds should be kept aside for workshops, exhibitions and also assist teachers production process.

\section{REFERENCES}

[1] Inyang-Abia, M. E. (2015). Essentials of educational technology. A handbook for educations and media practitioners. Calabar: Wusen Press. Ltd.

[2] Ibe-Bassey, G. S. (2004). Principles and practice of instructional communications. Uyo: Dorand Publishers.

[3] Ekpo-Eloma, E. O. (2007). Teachers' utilization of instructional materials and students' academic performance in social studies. Unpublished M.Sc Thesis. Uyo: University of Uyo.

[4] Mangal, S. K. \& Mangal, U. (2009). Essentials of educational technology. New Delhi: Phi Learning Private Ltd.

[5] Elekwa, I. \& Eze, R. (2002). Foundations of educational technology. Lagos: Logicate Media

[6] Shepard, R. L. (1999). Making our nonpoint source pollution education programs effective. Journal of Extension, 37(5).

[7] Romiszowski, A. J. (1988). The selection and use of instructional media ( $2^{\text {nd }}$ ed). London: Kegan Paul, 5(1).

[8] Ekpo-Eloma, E. O. (2021). Themes in educational technology. Calabar: University of Calabar Press.

[9] Goldstein, O \& Ropo, E. (2021). Preparing student teachers to teach with technology: Case studies in Finland and Israel. International Journal of Integrating Technology in Education, 10(2): 19-35. 


\section{Appendix 1}

\section{Pre-Knowledge Instructional Material Improvisation Questionnaire}

Section A (Personal Data)

2. Gender: Male [ ] Female [ ]

\section{Section B}

\begin{tabular}{|l|l|l|l|l|l|}
\hline S/n & Statement & SA & A & D & SD \\
\hline 1. & There are many levels of production of instructional materials. & & & & \\
\hline 2. & Production can be carried out at any level. & & & & \\
\hline 3. & Creativity/originality level is the highest level of production. & & & & \\
\hline 4. & Basic skills are needed in production of instructional materials. & & & \\
\hline 5. & $\begin{array}{l}\text { In production, observation of an existing material is very } \\
\text { important. }\end{array}$ & & & \\
\hline 6. & The skill of measurement is needed. & & & \\
\hline 7. & Colour is a key design element. & & & \\
\hline 8. & As a media designer, lettering should be considered. & & \\
\hline 9. & $\begin{array}{l}\text { Cutting tools are very essential in the production of instructional } \\
\text { materials. }\end{array}$ & & & \\
\hline 10. & $\begin{array}{l}\text { In utilizing any instructional materials, it must be relevant to } \\
\text { instructional objectives. }\end{array}$ & & & \\
\hline 11. & Materials should be pre-viewed before utilization. & & & \\
\hline 12. & $\begin{array}{l}\text { Materials for teaching and learning should reflect learners' } \\
\text { characteristics. }\end{array}$ & & & \\
\hline 13. & $\begin{array}{l}\text { As a teacher material to be used should be easily manipulated by } \\
\text { the teacher. }\end{array}$ & & & \\
\hline 14. & Instructional material used should be content accurate. & & & \\
\hline 15. & In using any material, the learner must be prepared. & & & \\
\hline 16. & $\begin{array}{l}\text { The learning environment where the material is to be used should } \\
\text { be clean. }\end{array}$ & & & \\
\hline 17. & Instructional materials should only be used before the lesson. & & & \\
\hline 18. & Materials for instruction should be evaluated before use. & & & \\
\hline 19. & $\begin{array}{l}\text { Instructional materials used should reflect the teaching method } \\
\text { used. }\end{array}$ & & & & \\
\hline 20. & Material used should evoke learners' participation. & & & \\
\hline
\end{tabular}


Appendix II

Post-Knowledge Instructional Material Improvisation Questionnaire

1. Name of School

Section A (Personal Data)

2. Gender: Male [ ] Female [ ]

Section B

\begin{tabular}{|c|c|c|c|c|c|}
\hline $\mathbf{S} / \mathbf{n}$ & Statement & $\mathbf{S A}$ & $\mathbf{A}$ & $\mathbf{D}$ & SD \\
\hline 1. & There are many levels of production of instructional materials. & & & & \\
\hline 2. & Production can be carried out at any level. & & & & \\
\hline 3. & Creativity/originality level is the highest level of production. & & & & \\
\hline 4. & Basic skills are needed in production of instructional materials. & & & & \\
\hline 5. & $\begin{array}{l}\text { In production, observation of an existing material is very } \\
\text { important. }\end{array}$ & & & & \\
\hline 6. & The skill of measurement is needed. & & & & \\
\hline 7. & Colour is a key design element. & & & & \\
\hline 8. & As a media designer, lettering should be considered. & & & & \\
\hline 9. & $\begin{array}{l}\text { Cutting tools are very essential in the production of instructional } \\
\text { materials. }\end{array}$ & & & & \\
\hline 10. & $\begin{array}{l}\text { In utilizing any instructional materials, it must be relevant to } \\
\text { instructional objectives. }\end{array}$ & & & & \\
\hline 11. & Materials should be pre-viewed before utilization. & & & & \\
\hline 12. & $\begin{array}{l}\text { Materials for teaching and learning should reflect learners' } \\
\text { characteristics. }\end{array}$ & & & & \\
\hline 13. & $\begin{array}{l}\text { As a teacher material to be used should be easily manipulated by } \\
\text { the teacher. }\end{array}$ & & & & \\
\hline 14. & Instructional material used should be content accurate. & & & & \\
\hline 15. & In using any material, the learner must be prepared. & & & & \\
\hline 16. & $\begin{array}{l}\text { The learning environment where the material is to be used should } \\
\text { be clean. }\end{array}$ & & & & \\
\hline 17. & Instructional materials should only be used before the lesson. & & & & \\
\hline 18. & Materials for instruction should be evaluated before use. & & & & \\
\hline 19. & $\begin{array}{l}\text { Instructional materials used should reflect the teaching method } \\
\text { used. }\end{array}$ & & & & \\
\hline 20. & Material used should evoke learners' participation. & & & & \\
\hline
\end{tabular}


International Journal on Integrating Technology in Education (IJITE), Vol.10, No.4, December 2021

\section{AUTHORS BIOGRAPHY}

1. Ekpo Ekpo-Eloma is a Lecturer in the Department of Curriculum and Teaching, Faculty of Educational Foundation Studies, University of Calabar, Nigeria. He holds a M.Sc(Ed) in Educational Technology, and a Ph. D in view. His research interest is in Instructional System Design (ISD), Broadcasting and Scripting for the Media, Digital Education and Educational Resource Centres and Management.

$\mathrm{He}$ is a member of some professional bodies, including Educational Media and Technology Association of Nigeria and Curriculum Organization of Nigeria. He has equally attended several conferences, workshops and seminars in Educational Technology and other related fields. He is the author of Themes in Educational Technology (2021).

2. Effiong, Abigail Aniefiok (Ph.D) is a lecturer in the Department of Curriculum and Teaching (Educational Technology Unit) University of Calabar. She holds a B. Ed, M. Sc \& $\mathrm{Ph}$. D degrees in Educational Technology. Her research interests are in Instructional System Design and Resource-Based Learning. She has scholarly articles published in reputable journals. She is a member of Educational Media and Technology Association of Nigeria and Curriculum Organization of Nigeria. She has equally attended several conferences, workshops and seminars in Educational Technology and other related fields.
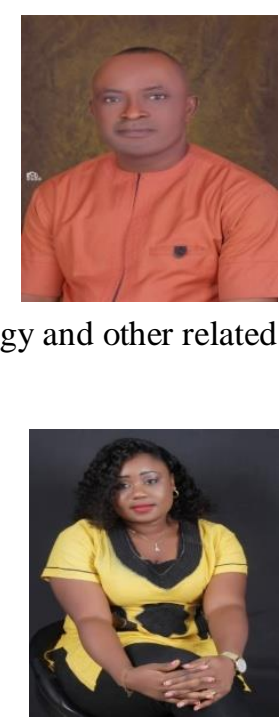